\author{
Alexa STOICESCU \\ ORCID: 0000-0001-7381-7247 \\ Universitatea din București
}

\title{
Een labyrint voor onze tijd. Het metaverhaal van de metropool in Paul van Ostaijens grotesken
}

\begin{abstract}
Apart from poetry, Paul van Ostaijen also wrote grotesque prose. The grotesque shows an inverted world that is equally logical as the real world but governed by different norms and an upside-down morality. It is alienating and familiar at the same time. The grotesque texts reflect on the grand narratives of modernism. In this article, I focus on the image of the metropolis in three stories: De kudde van Claire, De gehouden hotelsleutel and De verloren huissleutel. Firstly, I define the concept of the grotesque. Then, I discuss van Ostaijen's time in Berlin, before I turn to the metropolis and its inhabitants. They seem to desperately hold on to a logical and dual organisation of their city, lives and world, yet van Ostaijen undermines this dualistic world vision and positions his prose in the domain of ambiguity, in a labyrinth that may be the only answer to the question of the crisis imposed by reality.
\end{abstract}

Keywords: grotesque, Paul van Ostaijen, metropolis, big city, grand narrative, Berlin, decor, marionettes.

\section{Inleiding}

De Vlaamse avant-gardist Paul van Ostaijen (1896-1928) stuitte in het eerste kwart van de twintigste eeuw onder andere op de gevolgen van een wereldoorlog, een financiële crisis, armoede, tegenstrijdigheden, metropolen waarin de mens zich ontworteld voelde, een overmacht van corporaties, corruptie, kapotte idealen, de teleurstelling van zijn vertrouwen in Europese waarden, in het kort: een 'verkeerde wereld'. Tegelijk staat de moderne tijd echter bekend om antwoorden op de crisis, namelijk om processen van mechanisering, bureaucratisering, rationalisering, de verlichting, de secularisatie - vijf discoursen, die 
Thomas Vaessens 'moderne verhalen' (Vaessens 1998: 22) noemt. Daar kan nog meer aan worden toegevoegd: het geloof in de vooruitgang, de industrialisatie of de democratisering, maar ook in de natie. De "van zijn eigen wereld vervreemde mens [kon] destijds houvast zoeken in een verhaal" (Vaessens 1998: 19), gaat Vaessens door. Deze strategieën om houvast te zoeken in het verhaal worden toegepast door de wetenschappers, maar ook door de grotendeels in metropolen wonende kunstenaars.

Paul van Ostaijen staat volgens Vaessens bekend als modernist, als een gedesoriënteerde, met zijn identiteit worstelende intellectueel (vgl. Vaessens 1998: 12), die zich terugtrekt en vanaf een afstand de wereld bekijkt. Hij streeft naar het autonome woord en naar 'ontindividualisering' (vgl. bijvoorbeeld Van Ostaijens tekst "Et voilá. Een inleidend manifest"). Hij wordt 'de grootste baanbreker van het modernisme in Vlaanderen' (Hadermann 1985: 426) genoemd. Bij hem vindt de typisch modernistische ambivalentie zijn uitdrukking (vgl. Vaessens 1998: 30). Tegelijkertijd is hij een geëngageerde avant-gardist. "Actie en opstand tegen de gevestigde orde: dát is Van Ostaijen," (Vaessens 1998: 29) poneert sterk Vaessens. Van Ostaijen is geboren in Antwerpen en heeft daar kort meegedaan aan een activistische groep die er flamingantistische opvattingen op nahield. Hij sympathiseerde met het flamingantisme in de context van een internationaal broederschap en een kosmische eenheid, die vooral ook in de bundels Music-Hall en Het Sienjaal weerklang vinden. In deze bundels bewerkt hij de volgende thema's: de bioscoop, de technologische ontwikkelingen en de grote stad - een "Abattoir van al de illuzies: tentaculaire grootstraat! (Van Ostaijen 1987: 95, 96), waarin de mens zich tegelijk verborgen en vervreemd voelt (vgl. bijvoorbeeld het titelgedicht uit Music-Hall, waarin de mensen één zijn in een roes van geluk en dan weer pijnlijk alleen). Zijn proza is echter afstandelijk, geconcentreerder, moeilijker te begrijpen en minder besproken. Het is postuum uitgegeven - de eerste bundel, Vogelvrij, in 1928, en de rest van de teksten pas in zijn Verzameld werk in 1954. Uit die vermeende ontoegankelijkheid van Van Ostaijens proza kwam een nieuwsgierigheid voort, die de aanzet voor dit artikel was. Ik was benieuwd naar het beeld van de metropool, naar de karakterisering van de personages en naar de worsteling met het gebrek aan antwoorden op de grote vragen van de moderne tijd, vragen waarop Van Ostaijen in zijn poëzie steeds wisselende antwoorden gaf. Mijn hypothese is dat de grotesken de grote stad oproepen als een nieuwe religie, de metropool als een metaverhaal van het modernisme. Het artikel wordt daarom geleid door de volgende vragen: Welke gedaante krijgen de metropool en zijn personages in Van Ostaijens groteske proza? Welk wereldbeeld stamt hieruit voort? En: bevestigt of ondermijnt dit beeld de modernistische metaverhalen?

Het artikel bevat een drietal onderdelen. Eerst bespreek ik de term "grotesk", om het door Van Ostaijen gebruikte genre nauwer te definiëren en het in een bredere traditie te plaatsen. Dan neem ik de filosofie van Salomo Friedlaender onder 
de loep, die, zoals ik zal laten zien, als inspiratiebron voor de grotesken geldt. Ten tweede ga ik uitgebreider in op de Berlijnse context en de ontstaansgeschiedenis van de grotesken. Ten derde analyseer ik het stads- en wereldbeeld in drie teksten: De kudde van Claire of de maagdelijke bommelaarster, De gehouden hotelsleutel of de kleine, domme daad en De verloren huissleutel. Hoe het komt of zie-je wel. Juist deze drie teksten zijn gekozen, omdat hierin de beschrijving van de metropool als hoofdpersonage beschouwd kan worden. In alle drie worden ernstige pogingen ondernomen de overzichtelijkheid en logica van de organisatie van de metropolen te laten zien. En toch wringt er iets waardoor de logische opbouw wankelt: de redenering wordt tot in het absurde doorgetrokken en een steeds aanwezige verteller verstoort door vertellerscommentaar de onbevangen lezing. Bij elk verhaal ligt op dit fenomeen de focus. In de conclusie beantwoord ik de vraag of deze grotesken het beeld van de metaverhalen van het modernisme bevestigen of ondermijnen.

\section{De wereld van de verkeerdheid}

Van Ostaijens grotesken creëren een vervreemdingseffect, zoals de schilderijen van Breugel zijn kijkers de wereld anders laten zien. In de recensie van een studie over Breugel spreekt Van Ostaijen zijn waardering uit voor zijn kunst, waarover hij beweert dat daarin de wereld zelf wordt uitgebeeld: "Breugel verwerpt zijn wereld niet, noch aanvaardt hij ze; hij noteert ze. Hoogstens zou men van Breugel kunnen zeggen dat hij zich vermaakt om het groteske van het objekt dezer notitie" (Van Ostaijen 1977: 343). Zijn wereld is er een "van het menselike poppespel" (Van Ostaijen 1977: 354), een "wereld der absolute verkeerdheid" (Van Ostaijen 1977: 354), niet meer dan een Jan-Klaas-kast, een zinloze architektuur die als koulisse dient. Met andere woorden: de kunstenaar noteert wat hij ziet, hij is een waarnemer van de kunstmatige, verkeerde en groteske wereld.

Kenmerken van de groteske voorstelling zijn: 1) het groteske verschijnt in tijden van maatschappelijke crisis, waarin mensen het gevoel hebben aan irrationaliteit overgeleverd te zijn, 2) het groteske is een reactie op de tegenstrijdigheden van de realiteit, 3) het groteske onthult het irrationele zonder het te verklaren, 4) de groteske deformatie en deconstructie wordt bepaald door de spanning tussen de gruwel en het belachelijke en 5) het effect van het groteske komt voort uit het onvermogen van de lezer een duidelijke betekenis toe te kennen aan de tekst, uit de spanning tussen realiteit en irrationaliteit en uit het ontbreken van een duidelijk einde (vgl. Kötz 2001: 46-50). Al lijken de grotesken zich ver van elke werkelijkheid te positioneren, ze leggen door deze opgesomde karaktereigenschappen juist de nauwe relatie met de realiteit van de tijd bloot. Volgens Beekman is de tekstuele wereld juist mimethisch: "It is a world of perspicacity, structure, autho- 
rity, argumentation and rationalization, just like the world of our daily lives. The difference lies in the fact that this world is constructed on a foundation of anarchy. Behind the looking glass of reality lies a world reflected from our world, similarities between the two are inversely proportional to our standards. Through the looking glass lies a world gone amok in a logical manner" (Beekman 25). Het groteske representeert dus een omgekeerde wereld, die een logische karikatuur van de realiteit vormt. Het is deze wereld, maar met een masker op. En juist in dit spel van verstoppertje spelen ligt de kracht van de teksten en de kritiek op de afgebrokkelde, absurdistische realiteit. Dat doet de schrijver van het groteske door ironie en humor, door komedie en tragikomedie: "The paradox of using man's facultas ludendi to depict a fearful universe stems from the inability to write a tragedy about a world where the absurd is a daily headline. But comedy creates distance, which enable the writer to defy the horrible reality of his world by playing with it" (Beekman 1970: 7). Het gaat om het lachen, soms om een absurd of wanhopig lachen. De grotesken zijn a-logisch. Zij bevatten namelijk een logica die averechts op de norm staat. Van Ostaijen schetst een niet-officiële wereld en geeft aandacht aan het door de norm niet geaccepteerde deel van de maatschappij: de prostituees en hun bezoekers, geslachtsziektes, rasta's en andere figuren die de afwijkende normen representeren. Hij doet echter meer dan alleen de kenmerken van het genre bevestigen. De Vlaamse auteur bevindt zich in de traditie van de grotesken, maar geeft er een filosofische draai aan, geïnspireerd door de "spirituele filosoof" Salomo(n) Friedlaender, die hij in het kunstenaarscafé "Café des Westens" in Berlijn ontmoet. Onder het pseudoniem Mynona (omkering van anoniem) schreef hij 'filosofische' grotesken. In zijn boek Die schöpferische Indifferenz (1918) [De scheppende onverschilligheid] heeft hij het over de ontkrachting van de polariteit tussen subject en object, tussen ik en de wereld. Het subject kan dit onderscheid opheffen mits hij vertrekt van het nulpunt, van het absolute. Ondanks Kants conclusie dat "das Ding an sich" niet objectief kenbaar is en Nietzsches aankondiging van de dood van God, ziet Friedlaender een nieuw fundament van het objectieve denken. De wereld is voor de filosoof polair, zij is opgebouwd uit verschil, uit pool en tegenpool. De scheppingskracht ligt in het ik, dat weliswaar subjectief is, maar niettemin de enige schepper en kenner van de wereld. Hij is per definitie subjectief, maar er bestaat een mogelijkheid om tot objectiviteit te komen, om het denken weer te aarden. In het centrum van de differentie tussen pool en tegenpool ligt het punt van indifferentie, waarin het onderscheid wordt opgeheven. "Nur das Subjekt ist in der Lage, als Indifferenzpunkt der Welt zu fungieren, das es als einziges alle Bedingungen der Differenz erfüllt" (Kötz 2001: 32), legt Kötz uit. Met andere woorden kan het subject tot onverschilligheid komen door het aannemen van het verschil en vanuit deze positie kan en moet hij iets zien te scheppen. De kunstenaar heeft de volgende taak: "Der groteske Humorist speziell hat den Willen, die Erinnerung an das göttlich geheimnisvolle Urbild echten Lebens 
dadurch aufzufrischen, dass er das Zerrbild dieses verschlossenen Paradieses bis ins Unmögliche absichtlich übertreibt" (Mynona, geciteerd in Kötz 2001: 62). Salomo Friedlaender oefende deze geschapen onverschilligheid als Mynona in zijn grotesken uit, waarin hij het verschil tussen goed en kwaad, man of vrouw, bewegen of stilstaan overdreven en provisorisch opheft. De fictieve werelden zijn een karikaturale afbeelding van de werkelijkheid, die op zijn beurt een vermomde verschijning van het "echte" leven is. De grotesken hebben daardoor een bevrijdende functie, die de mensen helpt de wereld vol 'Differenz' te doorstaan. Een vergelijkbare bevrijdende functie hadden ze ook voor Van Ostaijen, die hij voor de rest van zijn leven bleef schrijven (vgl. Beekman 1970: 12). Sterker nog: "Friedlaender is richtinggevend geweest voor Van Ostaijens 'definitieve' denken" (Spinoy 1994: 202). Door de desillusie in Berlijn is Van Ostaijen een nieuwe weg ingeslagen: “de 'burleske' richting in zijn proza en die van de 'fantastiek' in zijn poëzie, zodat er voor hem als kunstenaar eerder van een bevrijdende dan van een verlammende uitwerking sprake is" (Borgers 1996: 217). Mijn stelling is dat Van Ostaijen de spanning tussen het ik en de wereld, met name tussen het personage en de moderne metaverhalen in zijn groteske proza probeert op te heffen en zo een ruimte van ambivalentie probeert te creëren.

\section{De Berlijnse context}

In 1918 week hij uit naar Berlijn om te ontsnappen aan een veroordeling tot drie maanden gevangenisstraf en een geldboete wegens smaad tegen een katholieke kardinaal. De Berlijnse tijd was echter een teleurstelling. Hij kreeg geen baan, was in de drie jaren in Berlijn financieel afhankelijk van zijn vriendin Emmeke, die als model werkte, woonde in een duistere buurt, waar cocaïnesmokkelaars lanterfantten. Zelf was hij ook een tijd verslaafd aan cocaïne en snoof 'methodisch' voordat hij naar concerten ging, zoals een vriend het zich voor de geest haalt (vgl. Borgers 1996: 204). Hij hield van jazz, vooral van de improvisaties, van de ritmische jazz en van Chopin. Op politiek vlak zag hij vooral destructie. De Novemberrevolutie en de moord op Rosa Luxemburg en Karl Liebknecht betekenden nog een stap verder voor de desillusie van zijn politieke idealisme.

In een brief aan Peter Bayens, uitgever van het tijdschrift De Vlaamsche Gazet - Het laatste nieuws, schrijft hij: "Het is hier alles zo monotoon triestig. Een pisseblom kan hier zelfs niet groeien. (...) Nu nog een gewichtige zaak. Comme j'en ai soupé de l'allemagne, wil ik terug naar België. En zelf kan het me helemaal niet kloten dat ik eerst enkele maanden in de doos wordt [sic!] gestopt en soldaat moet zijn. Een ding: hier weg. (...). adjöh Berlin du Schöne Stadt!!!!!” (Borgers 1996: 291-295). Misschien kan de werkelijkheid die hij in Berlijn vond 'grotesk' worden genoemd, zoals later wordt uitgelegd. Daarom beweert hij zich terug te 
trekken uit de realiteit: "De natuurlijke wereld interesseert me niet meer zó sterk ook niet in aktivistiese zin" (Borgers 1996: 221). Hij lijkt zich terug te trekken in zijn literatuur. Het groteske transformeerde Van Ostaijen tot een scheppende kracht. In Berlijn schreef hij De feesten van angst en pijn, Bezette stad en onder andere het eerste scenario in het Nederlands De bankroet-jazz. Hier schreef hij ook grotesk proza.

Berlijn mag voor Van Ostaijen op politiek en sociaal vlak wel een teleurstelling zijn geweest, maar dat neemt niet weg dat dit zijn meest productieve literaire periode was. Berlijn was de stad van het expressionisme, van het kubisme en van het dadaïsme. Berlijn was "het artistieke Walhalla" (Vaessens 1998: 29), een nachtmerrie vol met artistiek potentieel. Onder zijn vrienden zijn bijvoorbeeld Georg Grosz en Fritz Stuckenberg te noemen, wier schilderijen hij waardeerde. In de zomer van 1920 ondernam hij een reis naar Seeshaupt, waar de schilder Heinrich Campendonk en zijn vrouw woonden. Samen beklommen ze de Benediktenwand, een steile berg. Van Ostaijen raakte door hoogtevrees bevangen en bereikte met grote moeite de top. Boven genoot hij van het uitzicht en van zijn prestatie de klimtocht toch te hebben overleefd. Hier begon wat Borgers zijn "ontnuchteringsproces" (Borgers 1996: 300) noemt en hier schreef hij ook het gedicht Malheur, een van de vier gedichten, die Van Ostaijen eerst de titel Kritiese gedichten (vgl. Borgers 1996: 588) geeft. Malheur vertelt een absurdistisch voorval. De privaatdocent K. probeert zijn sigaar Uebersee Bismarck aan te steken, maar het waait en zijn hoge hoed vliegt in de afgrond. Hij springt hem achterna en "zo gelukt het de heer K. gelijktijdig met zijn hoge hoed // de afgrond te bereiken // Ongedeerde hoge hoed R.I.P. privaatdocent K." (Van Ostaijen Verzamelde gedichten 423). Het blinde geloof in het burgerlijke leven - gerepresenteerd door de hoed - trekt Van Ostaijen door tot in het absurde. Zo zette hij meteen de toon. Met deze gedichten, waarvan er een "Derde groteske" heet, bracht Van Ostaijen volgens Borgers een relativerend element in zijn werk (vgl. Borgers 1996: 300). Dit relativerende element was echter al eerder aanwezig. Reeds in 1919 was hij begonnen grotesken te schrijven, onder de invloed van Mynona. ${ }^{1}$ Over zijn eerste groteske van grotere omvang schrijft Van Ostaijen dat hij werkt aan "een novelle, waarin [hij] de mensen probeer[t] voor de aap te houden" (Borgers 1996: 221). Hij had het over de in van maart tot mei 1919 geschreven tekst De kudde van Claire of de maagdelijke bommelaarster. In dezelfde brief aan een Antwerpse vriend vervolgt hij: "Positieve kritiek: bral. Ik voel tans voor novellen waar je zo heerlik in kunt zwansen. De mensen zijn niet waard gekritiseerd te worden. Enkel stof voor burleske novellen" (Borgers 1996: 221). Uit dit citaat kan men concluderen dat de grotesken voor Van Ostaijen slechts een literair spel zijn, voor zijn eigen plezier

${ }^{1}$ Andere literaire voorbeelden van Paul van Ostaijen, met wiens werk hij vertrouwd was en door wie de interesse voor het groteske wellicht is ontstaan zijn Paul Scheerbart, Gustav Meyrink, Christian Morgenstern of Kafka (zie Beekman 1970: 8-10 of Borgers 1996: 216-22). 
geschreven. Toch representeren de mensen zijn "stof", zijn inspiratiebron, de basis voor zijn mimesis.

De thema's van de grotesken zijn onder andere het nadenken over Europa, corruptie, vaderlandsliefde, pessimisme, het noodlot van het individu, schijn en wezen, moraal, maar ook seksualiteit en het lichaam. Van Ostaijens grotesken gaan verder over de mogelijkheden van de mens om in vrijheid te leven en over de vraag of de mensen niet eerder in een zelfgekozen kooi leven, zoals in Het gevang in de hemel, of over de corporaties als een nieuw godsdienst, zoals bijvoorbeeld in De lotgevallen van de Mercurius, maatschappij tot exploitatie der valse munterij of over de absurde werking van een politieke partij, zoals in Glans en verval van een politiek man. De burger komt in deze teksten veelvuldig voor en is zelfs de perfecte bewoner van de groteske wereld (vgl. Beekman 1970: 40). Hij wordt echter geïroniseerd, zoals bijvoorbeeld in De overtuiging van notaris Telleke, waarin de notaris uit angst dat er in de trein een ongeluk zou kunnen gebeuren, er zelf uit springt. In De noodlottige historie van Scholem Weissbinder wordt het hoofdpersonage beheerst door zijn obsessie dat de das, die hij elke dag moet ombinden, eigenlijk een wurginstrument is. Elke dag lokt de dood door dit burgerlijke voorwerp en de verleiding wordt onuitstaanbaar om de das dichter te knopen. Hij vlucht naar Azië, een veilige haven voor alle "zenuwoverprikkelde Europeanen" (Van Ostaijen 1966: 63). Hoeren komen voor als leidende figuren, als dragers van de norm. In De verloren huissleutel geeft syfilis pas een identiteit aan de stedelingen. Soms lijken de grotesken op cartoons met onechte personages, zoals het geval is in De kudde van Claire, maar ook in Het bordeel van Ika Loch. Veel grotesken spelen in metropolen die worden beheerst door een dualistische redenering, lijken toonbeelden van moderniteit en vooruitgang te zijn en suggereren duidelijke antwoorden op de stad als nieuwe religie.

\section{Het beeld van de metropool}

In wat volgt worden er drie perspectieven van de metropool gepresenteerd: één waarin het hoofdpersonage zich met de stad identificeert, een andere waarin de stad de ondergang van de hoofdfiguur representeert en weer een andere waarin de groteske logica de stad geheel overneemt. De metropool speelt in deze teksten de rol van drager van verschillende metaverhalen: dat van de secularisatie en de vervanging van God door een andere instantie, dat van de decadentie en de roes en tenslotte het verhaal van de natievorming.

In De kudde van Claire of de maagdelijke bommelaarster is het kernwoord de vereenzelviging met de metropool. Claire is een achttienjarige met een liberale, vermoedelijk overspelige en drankzuchtige vader en een excentrieke, femme-fataal-achtige, maar toch zedevolle moeder. Claire geniet van het stadsleven, zij 
is een "koffiehuisbloem" (Van Ostaijen 1966: 157), zij gaat naar five-o'clocks en houdt van dansen en het lezen van romans. Voor haar is het leven eenvoudig mooi. Tientallen rasta's, rijke jonge mannen vormen haar kudde. "De rasta's waren poppen. Massacre des innocents... Zij had slechts te kiezen op wie zij haar bal werpen zou" (Van Ostaijen 1966: 154), wordt zelfs duidelijk geponeerd. En even later: "De poppekast stond voor haar open, zij had slechts te kiezen. Tussen haar en een elfjarig kind was weinig verschil. Zij betrachtte haar marionetten net zó als een kind haar porseleinen pop" (Van Ostaijen 1966: 155). De personages in de grotesken zijn typologieën, flat characters, geen zich ontwikkelende figuren, maar slechts dragers van ideeën (vgl. Borgers 1996: 222). Ze zijn eendimensionaal, ze gedragen zich mechanisch en uniform in dit universum, waar Claire voor God speelt. Voor haar is alles vermaak, want zij bekijkt alles met een gedistantieerd amusement. Zij blijft maagd en wacht op de echte liefde, die echter niet uit dit decor mag verschijnen. Van haar achttiende tot haar negentiende speelt Claire een toneel in het decor van de grote stad en, al staat ze in de stad bekend als een jonge vrouw van lichte zeden, is er geen enkel bewijs dat ze haar maagdelijkheid, haar superioriteit en haar afstandelijke karakter verliest. Zij geniet slechts van het mondaine leven. Op het einde van het verhaal trouwt ze met een jonge man die door haar vader is uitgekozen. Haar toekomstige echtgenoot was de enige man die haar imponeerde. "De rasta's waren diep geroerd" (Van Ostaijen 1966: 165), maar hun leven ging rustig door.

Verschillende aspecten verstoren een onbevangen lezing van de tekst. Wat meteen opvalt, zijn de voortdurende tweedelingen die de verteller opstelt. Er zijn twee soorten mannen: de vieux-marcheurs (oudere, rancuneuze mannen) en de rasta's (jongere rijke mannen, die speels met de kansen van de grote stad omgaan en alles tot een succesverhaal kunnen omvormen). Beide soorten mannen handelen op een logische manier en geloven sterk in hun mening. De rasta handelt alles snel af: "Volgens zijn opvatting bestaan er slechts twee resultaten: ja of nee" (Van Ostaijen 1966: 150). Hij gebruikt een duidelijke causale keten: "Overtuiging schenkt rust. Is rust niet het hoogste vorm van geluk? De rasta vindt een gemakkelijke vorm van rust. Geluk heeft rust nodig. Geluk is rust. Overtuiging schenkt rust. Daarom is de rasta overtuigd. Langs alle zijden: de rasta is een gelukkig mens" (Van Ostaijen 1966: 154). De rasta's hoeven niet te twijfelen, want hun leven en overtuigingen zijn overzichtelijk. Ze handelen als stereotypen, als blok, niet als individuen.

Interessant is verder een tweedeling tussen de stad en het platteland. Het platteland is deïstisch, terwijl de stad kapitalistisch en atheïstisch is. In de stad wordt de "primitieve geloofsbehoefte" (Van Ostaijen 1966: 157) genegeerd. De realiteit wordt vervangen door esthetiek. De stad representeert de nieuwe natuur, zo sterk dat er sprake is van "stad-tuin" (Van Ostaijen 1966: 159) en van de vegetatieve, natuurlijke stad, die men op basis van de bovenstaande tweedeling aan het platteland zou 
toeschrijven: "Planten wassen in onze steden als in die van duizend-en-éen nacht. Onze steden zijn niet dode blokken. Zij zijn primair vegetatief in de helderheid van nieuwe lichten" (Van Ostaijen 1966: 159). De stad mag wel vegetatief heten, maar ze is kunstmatig, want geïnspireerd door literatuur en met name uit Duizend-en-eennacht, waarin de in elkaar vervlochten narratieven niet tot een einde komen. Alsof Scheherezade aan het woord was, wordt de tweedeling stad-natuur door de verteller nog verder uitvergroot. Er wordt nog een subcategorie ingevoerd. De stad lijkt onderworpen te zijn aan een dualistische scheiding: die tussen een materiële stad en een eerder kosmische stad. De materiële stad wordt beheerst door het kapitalisme en het geloof in het bezit. Terwijl deze stad zich nog "op de planeet aarde" (Van Ostaijen 1966: 158) bevindt, spreekt de verteller een pagina later over een stad die "bovenop de planeet aarde" (Van Ostaijen 1966: 159) ligt. Sterker nog: "De stad is in onmiddellike nabijheid van de sterren" (Van Ostaijen 1966: 159). De rationaliteit, de hiërarchie en de logica van deze onderscheidingen worden ondermijnd door het creëren van steeds nieuwe distincties. De ene stad vloeit in de andere stad over: "de materiële stad zinkt weg in de gapende kloven van een leeuwerikjubelende destruktie en een nieuwe stad verschijnt: feeërik, planetaries, kosmies..." (Van Ostaijen 1966: 160). Het Nietzscheaanse nihilisme dat in deze regels weerklinkt, gaat niet op, want de nieuwe stad wordt geregeerd door een bovennatuurlijke kracht, wat geenszins de onttovering van de wereld op het oog heeft. De oude religie wordt vervangen door een nieuwe mythe: "En de magiër legde zijn hand op het hoofd van de maagd en zij zag de nieuwe stad" (Van Ostaijen 1966: 160). De lezer ontdekt meerdere tweedelingen: de maagd Claire staat bekend als hoer. De "maagdelijke bommelaarster" uit de titel is al een paradox, als men Bommel opvat als een benaming van de Duivel. Ook als bommel de betekenis van een "bedrieglijk plan" draagt, contrasteren de twee onderdelen van de titel met elkaar. Claire lijkt het boze en het goede tegelijkertijd in zich te dragen en wellicht het verschil daartussen op te heffen, zoals even later wordt beweerd.

Een andere tegenstelling is die tussen de "rein decoratieve" (Van Ostaijen 1966: 153) liefde, die Claire voor de rasta's voelt en de echte, grote liefde. Terwijl de eerste alleen door een sympathie van "volledig synthetiese aard" (Van Ostaijen 1966: 153) gekenmerkt wordt, is de grote liefde "ratio. Claire kende geen dogma. Zij was vrouw in de ideaalste zin" (Van Ostaijen 1966: 155). Claire staat onder de macht van het ideaal. Zij wordt beschreven als "rationeel idealisties" (vgl. Van Ostaijen 1966: 151), als "kernrein idealistisch" (Van Ostaijen 1966: 151) of "matematies" (Van Ostaijen 1966: 149, 156). In haar vereenzelviging met de stad is ze superieur en primitief:

$\mathrm{Zij}$ is éen met de bodem. Wordt een heideblom in een kamer binnengebracht, zo is de ganse heide in de kamer. Daarom is Claire zo machtig: geen gebaar of geen woord is verkeerd; kan ook niet verkeerd zijn. Organies staat zij zo tegenover het koffiehuis als de heideblom tegenover de heide. (...) (Van Ostaijen 1966: 156f). 
In de stad komt de maagd Claire tot leven, als een Christusfiguur: "Tussen Claire en Kristus is er slechts het verschil van de grootheid hunner concentratie" (Van Ostaijen 1966: 162). De logische, beheerste figuur lijkt een nieuwe goddelijke instantie te zijn. Zij staat symbool voor het nieuwe moderne leven door haar afstand, rationaliteit en superieure primitiviteit. Zij doorbreekt de dualistische ordening. Bij de verklaring of Claire de avances van de rasta's heeft afgewezen of aangenomen, staat er: "Het afwijzen was een diepte vóór de beweging van het aannemen. Er zijn geen tegenstellingen die onoverbrugbaar zijn" (Van Ostaijen 1966: 161f.) In deze regels weerklinkt de filosofie van Friedlaender, die vond dat de mens als schepper van alles het verschil tussen pool en tegenpool kan opheffen, door zich te positioneren in het midden, in het punt van in-differentie. En Claire wordt inderdaad indifferent: "haar onverschilligheid was de noodzakelike bodem voor een nieuw verlangen" (Van Ostaijen 1966: 162). Of eerder nog: "De rasta's zijn kleine kinderen tegenover Claire's scheppende daad. Hun wil is artificieel; zij hebben geen geloof. Schepping is Claire vanzelfsprekende, onderbewuste noodzaak. De rasta's hebben niet haar primitiviteit" (Van Ostaijen 1966: 156f.). Maar Claire is niet de schepper van dit decor, zoals vaak in de tekst wordt gepretendeerd. Zij is slechts een Christusfiguur, een kleinere schepper. De verteller speelt opnieuw met de lezer, want er was al sprake van een scheppende bovennatuurlijke magiër. Het metaverhaal van de stad als nieuwe religie en van een superieure, belangeloze schepper wordt ondermijnd.

Los van de inhoud van de tekst, heeft de groteske vertelling een onbetrouwbare, alles controlerende alwetende ik-verteller, die een realistische lezing verder ondergraaft. $\mathrm{Al}$ in de introductie staat er:

De mensen echter die zó weinig waarheid en konsekwentie in hun leven brengen, verlangen echter van de literatuur detailverklaringen en zulke precision die als geheel overbodig zouden kunnen beschouwd worden. Dat ik deze verklaringen geef impliceert geen regel in deze zin. Ik wil hier ook bijvoegen dat ik aan zulke verklaringen niet het minste geloof hecht of ook niet het tegenovergestelde, dit is dat ik ze volkomen diskrediteer. Ik geef ze enkel om een verklaring te geven en beken dat ik ze zelf hier op staande voet verzon (Van Ostaijen 1966: 146).

Waarom zou de literatuur een antwoord moeten geven op vragen die de mensen zelf in de realiteit niet kunnen beantwoorden? De personages en de handelingen zijn verzonnen, de verteller pretendeert niet ze te kennen, hij zegt geen bewijzen te hebben voor wat hij vertelt, maar hij is er zo pijnlijk van bewust dat hij een abstracte auteur wordt die de buitenwereld met zich meesleept. Hij ironiseert in een voetnoot "de kommunistiese toekomststaat" (Van Ostaijen 1966: 149) en keurt de uitdrukking "op de man af gaan" af als een "overblijfsel van een strijdlustige massa-ideologie" (Van Ostaijen 1966: 149). De identiteit van Claires vader mag wellicht uitgekristalliseerd zijn in de jarenlange romanervaring van de verteller (vgl. Van Ostaijen 1966: 147), maar over Claire staat duidelijk dat zij van het leven geniet, ook zonder "het romaneske en het realisties romaneske" (Van 
Ostaijen 1966: 148). De verschillende realiteiten raken in elkaar verzeild, in dit decor van de metropool. De tekst eindigt met een ironie van de verteller tegenover de gewoonte van de "romancier" om de afloop van het verhaal niet te vertellen, ook al had hij daarvoor honderden bladzijden over zijn helden verteld. Hij zal dit niet doen: "Ik zal mijne lezers deze desillusie sparen. Mijn lezers kennen Claire. Zij weten dat zij, zonder in de extremiteit der rasta's te vallen, de grootstad lief had" (Van Ostaijen 1966: 164). En hij vertelt wat Claire en de brouwerszoon van elkaar vonden en hoe ze op elkaar verliefd zijn geworden. Hoewel dit geen relatie meer lijkt te hebben met de metropool noch Claires relatie ermee. Des te meer omdat de jonge man uit "het vlakke land" (Van Ostaijen 1966: 163) komt. Van Ostaijen laat de lezer op het einde teleurgesteld achter: hij heeft dualiteiten opgesteld die hij probeert te sluiten door deze belangeloze schepper van de nieuwe stad, maar ook dat blijkt een decor dat door een nog hogere instantie gecreëerd werd.

Terwijl Claire één is met de metropool maar eruit wegkomt, gaat het hoofdpersonage uit De gehouden hotelsleutel of de kleine, domme daad er te gronde aan. Tussen Josef la Tour en de verteller, die hem deze keer persoonlijk kent, heerst er een dualiteit. Josef, of Jef, staat symbool voor de roes, de drank, het overspel, voor het hoerenbezoek, terwijl de verteller de intellectueel speelt die thee drinkt en nooit zijn zelfbeheersing kwijtraakt. Ook dit Dionysisch-Apollinische verhaal speelt in een decor, of "op het toneel der wereld" (Van Ostaijen 1966: 222). De vrouwen zijn speelgoed in de handen van Josef, alleen krijgen ze hier Breugelse allures, ze worden demonische wezens met Van-Eyck-smoelen (vgl. Van Ostaijen 1966: 221) en zijn geen belangeloze heerseressen. Ze worden zelfs succubi genoemd, vrouwelijke duivelsverschijningen die aan een geslachtsgemeenschap deelnemen. Deze hoerenreligie wordt geregeerd door een "God-gigolo" (Van Ostaijen 1966: 225), waarmee er hier een poging wordt ondernomen om God te ondermijnen. De goddelijke figuur wordt vervangen door een god van de roes. Josef ziet de stad niet als zijn redder. Hij reist naar Brussel waar hij de sleutel van een hotelkamer krijgt en bewaart. Over zijn relatie tot de stad wordt beweerd: "Soms had hij deze stad lief. Liefde die groeide uit de diepte van de andere pool. In het oog van God die geen onkuisheid kent, is deze stad een drijvend wrak van zonde. Het was Josef een welbehagen te voelen hoe hij bij elke stad God met de voeten trad. Met dezelfde voeten die hij van God gekregen had" (Van Ostaijen 1966: 223). De liefde groeide uit de diepte van de andere pool en hiermee is de connectie tot de filosofie van Friedlaender weer aanwezig. Pool en tegenpool beheersen het menselijke denken en Josef probeert dit denken te vernietigen door het letterlijk met zijn voeten te stampen.

Josef betreedt de omgekeerde moraal van de stad en wordt hierin, evenals Claire, een nieuwe schepper. Hij wordt de God van deze averechtse wereld. En hij misbruikt zijn macht. Tegenover de prostituees wordt hij agressief, hij slaat en verkracht ze en in een roes vermoord hij een vrouw. De sleutel is het symbool van 
deze wereld van erotiek, roes, gekheid, geweld, maar ook van onzekerheid. Ook al voelt hij berouw, hij kan de sleutel niet weggooien. Hij hoopt dat zijn vrouw hem zal vinden, zodat hij eindelijk de volledige waarheid kan vertellen. De kleine, domme daad om de sleutel te houden wordt een groteske aangelegenheid: "Het was voortdurend de negatie van zich-zelf. Het werd grotesk met een traan en het had tevens een belachelike tragiek. / Hij haatte Brussel. Hij was Brussel zat" (Van Ostaijen 1966: 227). Hier wordt de stad direct verantwoordelijk gehouden voor de toestand waarin Josef verkeert. Hij zoekt verlossing, maar is niet bereid boete te doen. Zo vertelt hij: "Dat ik de goddelike krachten negeerde en de kristelike dualiteit van ziel en lichaam. Wel kan ik het lichaam van de wroeging wegwerpen, doch de ziel (de platoniese idee van de wroeging als ge wilt) kan ik niet losgeraken. (...) Wanneer men gezondigd heeft, is het niet genoeg te zeggen: ik heb niet gezondigd. Het wegwerpen van mijn sleutel is geen oplossing" (Van Ostaijen 1966: 228). Ook Josef gaat er niet zo ver in het nieuwe metaverhaal te domineren. Hij heeft gemikt op het lichamelijke, maar vergat het spirituele. Eerder onspectaculair vertelt hij uiteindelijk toch de waarheid, gaat naar de docks, geeft de sleutel aan een trimmer en gooit zich in het water. Jozef was te sterk gebonden aan de oude morele wereld en was niet in staat zijn nieuwe functie als God van de onkuisheid te accepteren. Er is echter hoop want hij geeft de sleutel eerst weg voordat hij zich in het water gooit. Dit symboliseert de moeilijke weg naar de nieuwe orde, naar een nieuwe religie. In deze beide grotesken is er nog een bepaalde moraliteit of godsvrees te herkennen: Claire trouwt met iemand buiten het decor van de metropool en Jozef doet boete voor zijn fouten. Ze zijn grotesk door het onechte decor en door de logische en nuchtere toon van de vertelling. Beide hoofdpersonages blijven echter karikaturaal in een decor dat ze niet kunnen controleren, want de verteller is alomtegenwoordig.

In De verloren huissleutel. Hoe het komt of zie-je wel echter is de grote stad volledig geperverteerd en de nieuwe God vindt hier pas echt zijn identiteit. Terwijl er in het vorige verhaal nog sprake was van een perversie die in een hotel plaatsvindt, is hier het hele decor dat van de buitenwereld. Er is namelijk geen sleutel meer voor de binnenwereld. Het hoofdpersonage is Hasdrubal Paaltjes, inspecteur van bruggen en wegen, 40 jaar oud, geliefd door de vrouwen en wonende in de stad X, een stad van een halve miljoen inwoners. Hij was de motor van de stad, de glorie van de stad, zijn polsslag. Op een avond komt hij thuis, maar vergeet zijn sleutel en overnacht in een bordeel waar hij syfilis krijgt. Hoewel de arts hem een seksueel dieet voorschrijft, blijft hij met de vrouwen van de stad gemeenschap hebben. Binnen de kortste tijd leidt de hele bevolking aan syfilis. Ook hier is veel vertellerscommentaar aanwezig, bijvoorbeeld: "Uit het vervolg van dit verhaal zal blijken dat het hier, om geen geringere katastrofe gaat dan deze van Babel of van Sodomma" (Van Ostaijen 1966: 81). De kwestie wordt een politiek probleem en uiteindelijk zondert de stad zich af van de rest van het land. De nieuwe stad krijgt 
nu pas haar naam Megalopolis, alsof pas deze ziekte de ware identiteit van de stad voorstelt. Alle paria's, alle verstotelingen, alle immigranten vinden toevlucht in deze vrijstad, waar de afwijking een modus vivendi wordt. Het groteske lichaam, mismaakt door ziekte, is de norm geworden. Er wordt een nieuwe geschiedenis geschreven, die de nieuwe nationale waarden promoot. Hasdrubal Paaltjes wordt gevierd als nationale held, de stad krijgt standbeelden, een nieuwe mythologie wordt geboren, er wordt een nieuwe nationale kleur gekozen, en uit drie kampen - de ratio-realisten, de psychologisten en de normalisten - wordt er getracht een coherente nationale ideologie te schrijven, zodat er aan het einde geconstateerd mag worden: "Reeds ver in het verleden lag het ontstaan van Megalopolis" (Van Ostaijen 1966 88). Hier speelt Van Ostaijen met een ander metaverhaal: dat van de heilbrengende natievorming. Een catastrofe als een aan syfilis lijdende bevolking wordt rationeel opgelost door het aanvaarden van de afwijking en door pogingen van positieve geschiedschrijving. Er blijft enkel de vraag over wat als basis van dit nieuwe metaverhaal moet gelden. Zo staat er in De verloren huissleutel: "Een fetischkultus de groten onder zijn landgenoten of medeburgers ter ere is een eigenschap die elk volk, elke stad zich tot doel en glorie heeft gesteld. En dat was bij de Megalopolensers niet anders. Enkel hadden zij een ander waardemaatstaf. Is het verkeerd de boom van goed en kwaad als het begin van de menselike waardedifferentiëring op te stellen, ten minste de boom van een bepaald goed en een bepaald kwaad?" (Van Ostaijen 1966: 86) Goed en kwaad zijn geen duidelijke begrippen meer, ze moeten eerst weer gedefinieerd worden.

In de teksten is er sprake van een tweedeling, wat Vaessens "het principium tertii exclusi" (Vaessens 1998: 64) noemt. Hij legt uit: "De ongrijpbare tweeslachtigheid ruimt het veld zodat de dualistische systematiek van de machthebbers niet in gevaar komt. Uitsluiting van de ambivalentie houdt, zoals steeds in Van Ostaijens proza, de dingen overzichtelijk" (Vaessens 1998: 64). Vaessens vindt dit interesse voor de starre logica en voor mathematische schema's en classificatie een kenmerk van "dit geëngageerde proza, waarin de auteur een essentiële eigenschap van de moderne samenleving aan de kaak stelt" (Vaessens 1998: 64). Beheersbaarheid en classificatie zijn de beste oplossing in crisistijden. Maar Van Ostaijen laat de keerzijde van deze metaverhalen zien: "Zijn groteske wereld is een karikatuur van die orde, pathetisch in stand gehouden door mathematisch-logisch redenerende personages, die hun omgeving met behulp van kaarsrechte lijnen tot een volstrekt onttoverd coördinatenstelsel maken" (Vaessens 1998: 72). Ambivalenties zijn ongewenst in Van Ostaijens proza (vgl. Vaessens 1998: 70). En toch zijn deze ambivalenties aanwezig. Ten eerste door de eindeloze classificaties. Ten tweede door de zich inmengende vertellers. Ten laatste door het doorschemeren van onzekerheid en andere relativerende aspecten. In De verloren huissleutel zijn er drie kampen die vechten om de beste verklaring. De ratio-realisten en de psychologisten geven verklaringen die de dualistische logica beantwoorden. De der- 
de groep echter, de nominalisten, die gehaat wordt door het volk en wiens status lijkt op dat van de joden in de samenleving, beweren geen kant-en-klare oplossing te geven. Hasdrubal, wiens naam stamt van een Carthaags generaal die door zijn eigen volk ter dood werd veroordeeld, alleen om dan weer gevierd te worden, is eerder een "mythologische figuur" en de verloren huissleutel een "mythologische voorstelling van het feit: onmogelijkheid naar het vaderland terug te keren" (Van Ostaijen 1966: 88). Het mythologiseren van de feiten is geen gewoonte van de groteske personages. Het duidt op interpretatie, op ambivalentie en op een eindeloos rondzwerven, dat niet past in de geclassificeerde samenleving. Ook Claire schonk alleen aandacht aan die rasta's bij wie zij een glimp van vrije wil herkent (vgl. Van Ostaijen 1966: 153) en de man met wie ze uiteindelijk trouwt imponeert haar juist omdat hij ambivalent is. Zij wist niet hoe zij op hem moest reageren: "Zij was geslagen" (Van Ostaijen 1966: 164), Met andere woorden hadden haar beheerstheid, rationaliteit en mathematisch denken berust op een strakke logica die nu doorbroken wordt door ambivalentie.

\section{Een labyrint voor onze tijd. Conclusie}

De metropool is in de teksten van Van Ostaijen slechts een decor, een "koulisse" met kwetsbare muren, een stad waarin een omgekeerde moraal aan de macht is, een onlogisch-logisch opgebouwde stad, waar wanorde de orde wordt, een stad waarin er een duidelijke despoot heerst, gesymboliseerd door een verteller die door vertellerscommentaar in de realiteit van de tekst ingrijpt en een absolute controle garandeert. Het is een stad van marionetten waarin de personages slechts machinale, groteske poppen zijn. Hoe verzonnen en overdreven de grotesken ook lijken, ze beantwoorden aan een van de kenmerken van het groteske proza: een raakvlak met de realiteit. Wat de boodschap van Van Ostaijens grotesken is, formuleert Spinoy: "Sie wollen zu autonomem, (selbst)kritischem und demystifizierendem Denken anspornen" (Spinoy 1988: 85). De grotesken sporen aan tot een autonoom, zelfkritisch en gedemystificeerd denken. Ook al beweerde Van Ostaijen niet meer geïnteresseerd te zijn in de echte wereld, in de nieuwe metropool, kroop de stad vermomd terug in zijn proza. Randfiguren spelen hier de hoofdrol en het moderne denken, gebaseerd op feiten en wetten en gedefinieerd door het onderbrengen in categorieën wordt geïroniseerd. Van Ostaijen reflecteert in deze grotesken op de moderne tijd, een tijd zonder houvast en met een oncontroleerbare snelheid. Hij geeft geen duidelijke antwoorden, evenmin als in zijn gedichten, relativeert de metaverhalen van de moderne wereld en geeft als enige mogelijke antwoord de ambivalentie die de lezer niet bevrijd uit het labyrint, maar die hem het wellicht leert begrijpen. 


\section{Bibliografie}

Van den Berg, Hubert (1995): "Tristan Tzaras Manifeste Dada 1918: Anti-Manifest oder manifestierte Indifferenz? Samuel Friedlaenders "Schöpferische Indifferenz" und das dadaistische Selbstverständnis". Neophilologus 79:3, 353-376.

Beekman, E.M. (1970): The Homeopathy of the Absurd: The Grotesque in Paul van Ostaijen's Creative Prose. Den Haag: Martinus Nijhoff.

Borgers, Gerrit (1996): Paul van Ostaijen. Een documentatie. Amsterdam: Bert Bakker.

Cardorff, Peter (1988): Friedlaender (Mynona) zur Einführung. Hamburg: Junius.

Edwards, Justin D., \& Rune Graulund (2013): Grotesque. London/New York: Routledge.

Freud, Sigmund (1919): "Das Unheimliche". Imago. Zeitschrift für Anwendung der Psychoanalyse auf die Geisteswissenschaften 5, 297-324.

Friedlaender, Salomo (1918): Schöpferische Indifferenz. Georg Müller: München.

Hadermann, Paul (1970): Het vuur in de verte. Antwerpen: Ontwikkeling.

Hadermann, Paul (1985): "Paul van Ostaijen". In: Gerrit Jan Van Bork \& Pieter Jozias Verkruijsse (red.), De Nederlandse en Vlaamse auteurs van middeleeuwen tot heden met inbegrip van de Friese auteurs. Weesp: De Haans, 426-428.

Kötz, Kathrin (2001): Die Prosa Paul van Ostaijens. Stilistische, poetologische und philosophische Korrespondenzen mit dem Werk von Mynona (Samono Friedlaender). Münster: Waxmann Verlag.

Kuxdorf, Manfred (1990): Der Schriftsteller Salomo Friedlaender/Mynona: Kommentator einer Epoche. Frankfurt: Peter Lang.

Nietzsche, Friedrich (1964): Der Wille zur Macht. Versuch einer Umwertung aller Werte. Stuttgart: Alfred Kröner Verlag.

Offermans, Cyrille (1984): "Heerlijk zwansen. Over de grotesken van Paul van Ostaijen”. Raster, 52-66.

Van Ostaijen, Paul (1966): Verzameld werk. Grotesken en ander proza. Antwerpen: Bert Bakker.

Van Ostaijen, Paul (1977): Verzameld werk. Besprekingen en beschouwingen. Antwerpen: Bert Bakker.

Van Ostaijen, Paul (1987): Verzamelde gedichten. Antwerpen: Bert Bakker.

Rodenko, Paul (1955): "De andere Paul van Ostayen". Nieuwe Rotterdamse courant, 9.04.1955.

Spinoy, Erik (1994): Twee handen in het lege. Paul van Ostaijen en het verhevene. Ongepubliceerd.

Spinoy, Erik (1998): "Dekonstruktion und Weltschmerz. Die paradoxe Prosa Paul van Ostaijens". In: Lut Missinne \& Loek Geeraerdts (red.), Paul van Ostaijen, die Avangarde und Berlin. Münster/Hamburg: LIT, 71-90.

Vaessens, Thomas (1998): Circus Dubio \& Schroom. Amsterdam: De Arbeiderspers.

Weller, Shane (2011): Modernism and Nihilism. Palgrave Macmillan.

Neerlandica Wratislaviensia 28, 2018

(C) for this edition by CNS 